\title{
ENDOPHYTIC BACTERIA FROM Pinus taeda L. AS BIOCONTROL AGENTS OF F usarium circinatum NIRENBERG \& O'DONNELL
}

\author{
Silvina Soria ${ }^{1}$, Raquel Alonso $^{1 *}$, and Lina Bettucci ${ }^{1}$
}

Fusarium circinatum Nirenberg \& O'Donnell, the pitch canker fungus, has been recently reported in Uruguay affecting Pinus taeda L. seedlings. The spread of this pathogen to plantations constitute a risk to forestry production. The aim of this work was to evaluate the inhibitory effect of live bacteria and their thermostable metabolites on $F$. circinatum growth in vitro. Four Bacillus subtilis strains and one of Burkholderia sp. isolated as P. taeda endophytes were evaluated as biological control agents of $F$. circinatum. Dual cultures between live bacteria and pathogen were performed. Furthermore, bacteria metabolites obtained from liquid cultures were sterilized and added to the culture media where fungus was grown. In this study all bacteria showed an antagonist effect on the pathogen growth arresting the mycelia at one $\mathrm{cm}$ of the edge of the bacteria colony. Bacteria thermostable metabolites reduced over 50\% fungal growth. These results demonstrates that endophytic bacteria, well adapted to live in host tissues, constitute a good alternative to control F. circinatum affecting Pinus seedlings.

Key words: Biological control, Bacillus sp., Burkholderia sp., pitch canker.

$\mathrm{T}$ he pitch canker fungus Fusarium circinatum Nirenberg and O’Donnell is a destructive pathogen that affects several Pinus species (Barnard and Blakeslee, 1980; Viljoen et al., 1994). The symptom more frequently associated to this pathogen is the presence of large resinous cankers on the main trunk and lateral branches of trees but it can also be associated to roots, shoots, cones, and seedlings. In plant seedlings aerial symptoms do not appear until the pathogen reach the trunk from lesions at soil level resulting in plant discoloration and needles drying. The disease has been detected in south eastern USA (Kuhlman et al., 1982), Mexico, South Africa, Chile, Japan, and Spain (Kobayashi and Muramoto, 1989; Guerra-Santos, 1999; Wingfield et al., 2002; Perez Sierra et al., 2007). Recently, in Uruguay this pathogen was detected on Pinus taeda L. seedlings from nurseries mainly affecting stem collar (Alonso and Bettucci, 2009).

According to Cook and Baker (1983) biological control can be defined as a reduction of the amount of inoculum or disease produced by the activity of a pathogen, based on the use of natural enemies or the use of compounds derived from its metabolism. Then, the biological control offers an alternative to the chemical products, contributing to minimize the negative consequences for human health and environment (Kim et al., 2003). Fungal diseases are

${ }^{1}$ Universidad de la República, Facultad de Ciencias-Facultad de Ingeniería, Montevideo, Uruguay.

*Corresponding author (raquela@fing.edu.uy).

Received: 15 September 2011.

Accepted: 25 May 2012. very frequent in nurseries and the chemical control of pathogens is the most common practice.

Bacillus subtilis has been identified as a potent antagonist against several fungal pathogens due to the production of antifungal compounds, antibiotics and proteases, hence is extensively used in agricultural systems (Todorova and Kozhuharova, 2009; Chen et al., 2009; Kinsella et al., 2009).

Burkholderia sp. is known to have beneficial effect on plant growth through the production of antifungal and other compounds that are able to suppress many soilborne plant pathogens (Holmes et al., 1998). Burkholderia cepacia is an ubiquitous soil organism that can be easily obtained and it has been studied as biocontrol agent of plant disease (Leisinger and Margraff, 1979). Many of its metabolites have been isolated and identified thus verifying its inhibitory effect on different plant pathogens such as fungus, bacteria and yeasts (Sopheareth et al., 2006), particularly on species of Pythium, Botrytis, Fusarium, and Rhizotocnia (Sijam and Dikin, 2005; Quan et al., 2006).

The abuse and misuse of chemical products can cause environmental and human health-related risks. On the other hand, little work has been performed on biological control of forest pathogens. Identification and action mode of antifungal compounds produced by an antagonist need to be studied.

The aim of this work was to evaluate the antagonist effect of both live bacteria and their thermostable metabolites of four Bacillus subtilis strains and one of Burkholderia sp. on Fusarium circinatum growth. 


\section{MATERIALS AND METHODS}

\section{Fungal and bacteria isolates}

Fusarium circinatum strains used in this work were all isolated from symptomatic Pinus taeda seedlings from two Pinus nurseries from Rivera and Florida Departments in Uruguay. The fungal isolates were identified by macro and micromorphological characteristics and verified by molecular analysis using CIRC1A and CIRC4A specific primers for F. circinatum (Schweigkofler et al., 2004). The isolates were maintained in potato dextrose agar (PDA). Bacteria were present as endophytes from Pinus seedlings and were isolated from stem healthy tissues. Those showing inhibitory effect on fungal growth were selected. The identification of bacteria strains were performed by molecular analysis of 16S RNA region. The cultures were maintained on triptone soy agar (TSA).

\section{Bacteria antagonist on $\boldsymbol{F}$. circinatum growth}

To evaluate the antagonist effect of different live bacteria, mycelia plugs from the edges of actively growing fungal cultures were placed in the center of Petri dish containing PDA. Four bacteria isolates were streaked on the same plates at equal distance from the fungal inocula. Plates with the fungal plug without bacteria were used as control. Plates were incubated at $25^{\circ} \mathrm{C}$ for $5 \mathrm{~d}$ to evaluate the inhibition activity of bacteria on the fungus. Each treatment was replicated five times. The fungal strains used were Fc 2052, Fc2053, Fc2054, and Fc2057. Bacteria strains of Bacillus subtilis used were B1, B2, B3, B4, and one strain of Burkholderia sp. (B5).

Observations of mycelia of the interaction zone between fungi and bacteria were performed under microscope.

The activity of bacteria thermostable metabolites was also evaluated. Liquid cultures of bacteria were performed transferring colonies of each bacterium to a $250 \mathrm{~mL}$ Erlenmeyer flask containing $100 \mathrm{~mL}$ of potato dextrose broth (PDB) and then incubated in a rotary shaker at 27 ${ }^{\circ} \mathrm{C}$ and $180 \mathrm{rpm}$ during $7 \mathrm{~d}$. Ten milliliters of each flask were transferred to a new flask with $90 \mathrm{~mL}$ of PDA. These new flasks were sterilized during $16 \mathrm{~min}$ at $121{ }^{\circ} \mathrm{C}$ and $1 \mathrm{~atm}$. The culture medium plus the metabolites were homogenized and $20 \mathrm{~mL}$ were placed on Petri dishes of $9 \mathrm{~cm}$ of diameter. Once the medium was solidified a plug of each fungal strain was placed in the centre of a dish. A fungal plug placed on PDA was used for control. Each treatment and control was replicated three times. Both treatments and controls were incubated at $25^{\circ} \mathrm{C}$ during 9 d. After incubation for $120 \mathrm{~h}$ the diameter of the colonies was measured daily during $4 \mathrm{~d}$ and compared with controls. The measures were made from the centre of the fungal plug to the edge of the colony. Two measures were taken which were then averaged. Percentage of inhibition growth and the rate of growth were calculated. To determine if there were differences in the rate of growth between the four fungal strains tested a One Way ANOVA test was made using the Sigma Stat 3.5 program.

\section{RESULTS AND DISCUSSION}

\section{Isolation of bacteria and screening of antifungal effect}

The screening of bacteria for antifungal activity against the Pinus pathogen F. circinatum showed that all of them exhibited growth inhibition against the pathogen. All the strains arrested the mycelium growth at $1 \mathrm{~cm}$ or more of the fungal colony margin (Figure 1). The development of an inhibition halo was observed between the fungal colonies and the bacteria inocula. This may be due to the production of bacterial metabolites that may diffuse in the culture medium and suppress the growth of $F$. circinatum. These results are consistent with those obtained by Nourozian et al. (2006) who evaluated the antagonist activity of different bacteria (Bacillus, Pseudomonas) against $F$. graminearum. They observed, in dual culture experiments, the formation of inhibition zones between bacteria and fungus.

The micromorphology of mycelia in the interaction zone showed a change in hyphal mode development, exhibiting empty, vacuolated and swollen hypha and a different ramification pattern.

\section{Effect of thermostable metabolites}

Despite metabolites of all strains showed an inhibitory effect against the fungus strains tested (Figure 2) all of them had a different incidence on the fungal growth (Figure 3).

There were significant differences among the bacterial strains. Growth inhibition on the strain Fc2052 was greater than to the other strains $(\mathrm{p} \leq 0.05)$ (Figure 2). On the other hand, from all strains of $B$. subtilis the strain $\mathrm{B} 2$ showed the lowest effect on the pathogen growth. Although the fungal strain Fc2053 showed a lesser growth than the control, the difference was not significant. The effect of metabolites of B. subtilis B1 on Fc2054 was greater than to other fungal strains. Metabolites from Burkholderia sp. evidenced a lesser effect on the growth of this pathogen. Metabolites of B1, B3, B4, and B5 reduced the growth of F. circinatum Fc2057over 50\% (Figure 2).

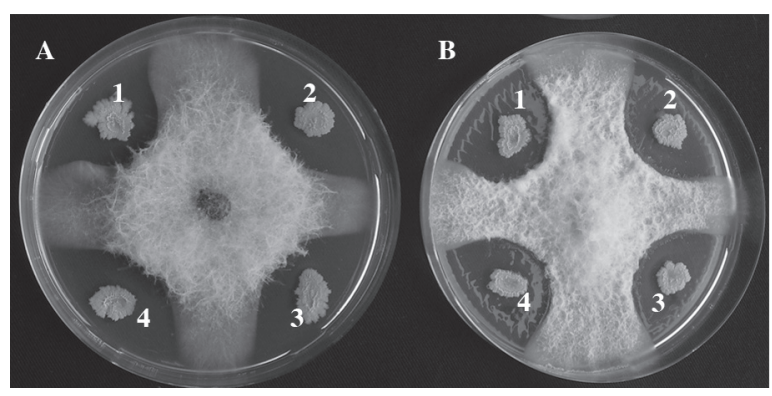

Figure 1. Inhibition halo produced on Fusarium circinatum strain FC2057 (A), and FC2053 (B) by Bacillus subtilis strains (1: B1; 2: B2; 3: B3; 4: B4). 


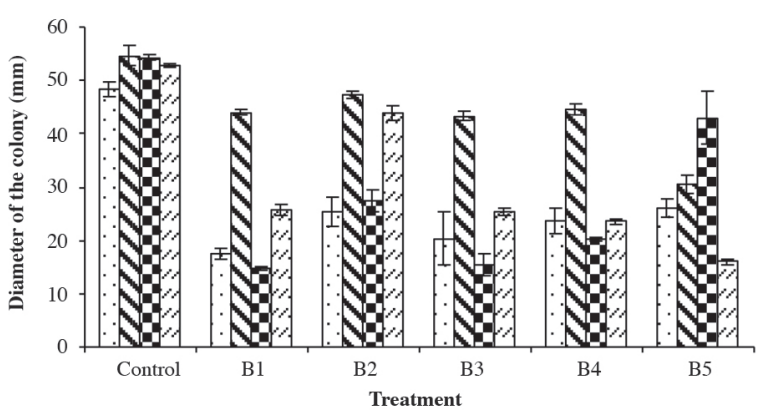

Figure 2. Antagonist effect of thermostable metabolites on Fusarium circinatum growth $( \pm \mathrm{SD})$.

Growth of F usarium circinatum strains Fc2052 [, Fc2053 \, Fc2054 and Fc2057 $\triangle$ after 5 days on culture media containing thermostable metabolites of Bacillus subtilis strains (B1, B2, B3, B4) and Burkholderia sp. (B5). Control: culture media without metabolites.

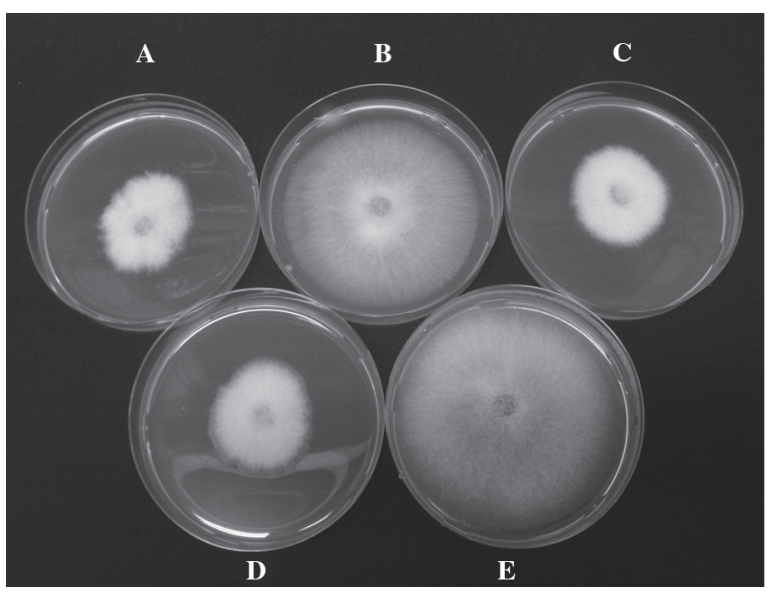

Figure 3. Growth of Fusarium circinatum strain Fc2057 on culture media containing thermostable metabolites of Bacillus subtilis strains (A: strain B1; B: strain B2; C: strain B3; D: strain B4; E: control, culture media without metabolites).

These results showed that the metabolites of Bacillus and Burkholderia tested, reduced the rate of growth of $F$. circinatum although some differences among fungal strains were observed. These findings suggest the possibility of using B. subtilis as biocontrol agent of Pinus pathogen $F$. circinatum, consistently with other studies where Bacillus has inhibitory effect against Fusarium spp. and other plant pathogen fungi (Moita et al., 2005; Kinsella et al., 2009). Recently, Burkholderia spp. have been used as biocontrol agents against fungal disease, including Fusarium spp. (Quan et al., 2006).

\section{CONCLUSIONS}

The bacteria that were present as endophytes of Pinus taeda seedlings were symptomless colonizers and apparently adapted to host tissues. This can constitute an advantage for using them as biocontrol agent of the pitch canker fungus on this host. The biological control could be an alternative to reduce the incidence of the pathogen in nurseries in order to avoid the expansion of the disease to the field. The active thermostable metabolites are also a very interesting alternative to chemical control and to avoid the use of living organisms. Both, B. subtilis and Burkholderia are not frequently used in forest management.

\section{ACKNOWLEDGEMENTS}

We thank Estella Reginensi and Ana Clara Bianchi for the identification of the bacteria used in this study.

Bacterias endófitas de Pinus taeda L. como agentes de control biológico de Fusarium circinatum Nirenberg \& O'Donnell. La presencia de Fusarium circinatum Niremberg \& O’Donnell, agente causal del cancro resinoso en pino, ha sido detectada recientemente en plántulas de Pinus taeda L. en Uruguay. La propagación de este patógeno en las plantaciones constituye un riesgo para la producción forestal. El objetivo de este trabajo fue determinar la capacidad inhibitoria de bacterias vivas y de sus metabolitos termoestables sobre el crecimiento de $F$. circinatum in vitro. Cuatro cepas de Bacillus subtilis y una de Burkholderia sp. aisladas como endófitas de P. taeda, fueron evaluadas como potenciales agentes de control biológico sobre $F$. circinatum. Para ello, se realizaron enfrentamientos directos entre las bacterias vivas y el micelio del patógeno. Por otra parte, los metabolitos bacterianos obtenidos de cultivos líquidos fueron esterilizados en autoclave y se incorporaron al medio de cultivo donde se hizo crecer el patógeno. En este estudio todas las bacterias mostraron un efecto antagónico sobre el crecimiento del patógeno, deteniéndose el avance del micelio a $1 \mathrm{~cm}$ del borde de la colonia bacteriana. Los metabolitos termoestables de las bacterias produjeron una disminución significativa en la tasa de crecimiento del hongo mayor al 50\%. Estos resultados muestran que las bacterias que viven dentro de los tejidos sanos del hospedante son una buena alternativa para el control del patógeno F. circinatum en plántulas de Pinus.

Palabras clave: control biológico, Bacillus sp., Burkholderia sp., cancro resinoso.

\section{LITERATURE CITED}

Alonso, R., and L. Bettucci. 2009. First report of the Pitch canker fungus Fusarium circinatum affecting Pinus taeda seedlings in Uruguay. Australasian Plant Disease Notes 4:91-92.

Barnard, E.L., and G.M. Blakeslee. 1980. Pitch canker of slash pine seedlings: a new disease in forest tree nurseries. Plant Disease 64:695-696.

Cook, R.J., and K.F. Baker. 1983. The nature and practice of biological control of plant pathogens. 593 p. APS Press, St. Paul, Minnesota, USA.

Chen, F., M. Wang, Y. Zheng, J. Luo, X. Yang, and X. Wang. 2009. Quantitative changes of plant defense enzymes and phytohormone in biocontrol of cucumber Fusarium wilt by Bacillus subtilis 
B579. World Journal of Microbiology and Biotechnology 26:675684.

Guerra-Santos, J.J. 1999. Pitch canker on Monterrey pine in Mexico. In Devey, M.E., A.C. Matheson, and T.R Gordon (eds.) Forestry and forest products. Current and potential impacts of pitch canker in Radiata pine. Technical Report Vol. 112. p. 58-61. CSIRO, Canberra, Australia.

Holmes, A., J. Govan, and R. Goldstein. 1998. Agricultural use of Burkholderia (Pseudomonas) cepacia: A threat to human health? Emerging Infectious Diseases 4:221-227.

Kim, H.S., J. Park, S.W. Choi, K.H. Choi, G.P. Lee, S.J. Ban, et al. 2003. Isolation and characterization of Bacillus strains for biological control. Journal of Microbiology 41:196-201.

Kinsella, K., C.P. Schulthess, T.F. Morris, and J.D. Stuart. 2009. Rapid quantification of Bacillus subtilis antibiotics in the rhizosphere. Soil Biology \& Biochemistry 41:374-379.

Kobayashi, T., and M. Muramoto. 1989. Pitch canker of Pinus luchuensis, a new disease of Japanese forests. Forests Pests 40:169-173.

Kuhlman, E.G., S.D. Dianis, and T.K. Smith. 1982. Epidemiology of pitch canker disease in a loblolly pine seed orchard in North Carolina. Phytopathology 72:1212-1216.

Leisinger, T., and R. Margraff. 1979. Secondary metabolites of fluorescent pseudomonads. Microbiological Reviews 43:422-442.

Moita, C., S.S. Feio, L. Nunes, M.J.M. Curto, and J.C. Roseiro. 2005. Optimization of physical factors on the production of active metabolites by Bacillus subtilis 355 against wood surface contaminant fungi. International Biodeterioration and Biodegradation 55:261-269.

Nourozian, J., H.R. Etebarian, and G. Khodakaramian. 2006. Biological control of Fusarium graminearum on wheat by antagonistic bacteria. Songklanakarin Journal of Science and Technology 28:29-38.
Perez Sierra, A., E. Landeras, M. Leon, M. Berbegal, J. GarcíaJiménez, and J. Armengol. 2007. Characterization of Fusarium circinatum from Pinus spp. in northern Spain. Mycological Research 111:832-839.

Quan, C.S., W. Zheng, Q. Liu, Y. Otha, and S.D. Fan. 2006. Isolation and characterization of a novel Burkholderia cepacia with strong antifungal activity against Rhizoctonia solani. Applied Microbial and Cell Physiology 72:1276-1284.

Sijam, K., and A. Dikin. 2005. Biochemical and physiological characterization of Burkholderia cepacia as biological control agent. International Journal of Agriculture and Biology 7:385388.

Schweigkofler, W., K. O`Donnell, and M. Garbelotto. 2004 Detection and quantification of airborne conidia of Fusarium circinatum, the causal agent of pine pitch canker, from California sites by using a real-time PCR approach combined with a simple spore trapping method. Applied and Environmental Microbiology 70:3512-3520.

Sopheareth. M., L. Seug-Je, H. Hoon, K. Yong-Wong, P. KeunHyung, C. Gyu-Suk, et al. 2006. Isolation and characterization of antifungal substances from Burkholderia sp. culture broth Current Microbiology 53:358-364.

Todorova, S., and L. Kozhuharova. 2009. Characteristics and antimicrobial activity of Bacillus subtilis strains isolated from soil. World Journal of Microbiology and Biotechnology 26:12071216.

Viljoen, A., M.J. Wingfield, and W.F.O. Marasas. 1994. First report of Fusarium subglutinans f. sp. pini on seedlings in South Africa. Plant Disease 78:309-312.

Wingfield, M.J., A. Jacobs, T.A. Coutinho, R. Ahumada, and B.D Wingfield. 2002. First report of the pitch canker fungus, Fusarium circinatum, on pines in Chile. Plant Pathology 51:397. 